\title{
ANALISIS POTENSI BUMDES MELALUI PENGEMBANGAN BAMBU SEBAGAI OBJEK WISATA DI DESA SENDIR KECAMATAN LENTENG KABUPATEN SUMENEP
}

\author{
Nailah Aka Kusuma ${ }^{1}$ \\ Evi Malia ${ }^{2}$ \\ ${ }^{1}$ Fakultas Ekonomi, Universitas Islam Madura, Indonesia \\ ${ }^{1}$ nailahakakusuma@gmail.com \\ ${ }^{2}$ Fakultas Ekonomi, Universitas Islam Madura, Indonesia \\ 2evi.malia@uim.ac.id
}

\begin{abstract}
The research is aims to make bamboo potential as a tourist attraction that supports government programs that will make Sumenep atourism city. Research method is descriptive qualitative method with data collection methods using interviews and field observation at Sendir vilage, Kecamatan Lenteng, Kabupaten Sumenep. Analysis of the data is using the miles and hubberman method. First with data reduction, data presentation and starting conclusions. The results of this research are Desa Sendir has the potential to be used as a tourist attraction with bamboo as a tourist attraction in terms of tourism potential sources. Facilities, and Ancillary. Desa Sendir must consider several inhibiting factors to find a solution so that the formation of a bamboo tourism village in Desa Sendir supported by all parties, tourism community and the government.
\end{abstract}

Keywords: Village, Bamboo Potential, Tourism Potential, BUMDES

\section{PENDAHULUAN}

Desa Wisata dalam kurun waktu lima tahun terakhir menjadi daya tarik tersendiri bagi para pecinta wisata baik wisatawan lokal maupun wisatawan asing. Terlebih lagi dengan adanya program dari Kementerian Desa tentang satu Desa satu BUMDes (Badan Usaha Milik Desa), setiap desa saling berlomba untuk menggali potensi desanyaagar menarik untuk dijadikan wisata desa. Banyak desa yang telah sukses membentuk desa wisata diantaranya Desa wisata Sungai Nyalo (Sumatera Barat), Desa wisata Madobak yang berasal dari Mentawai, Desa wisata Taman Sari Kabupaten Banyuwangi,
Desa wisata Pujon Kidul kabupaten Malang, Desa wisata Seigentung di Gunung Kidul, Desa wisata Ubud di Gianyar Bali, Desa Waturaka di Kabupaten Ende, Desa wisata umbul Ponggok di Klaten, Desa wisata Teluk Meranti (Riau), dan Desa Bontagula (Bontang). Sepuluh desa tersebut merupakan desa terbaik di Indonesia menurut Kemendes PDTT. Pada umumnya desa yang telah dibentuk menjadi desa wisata tersebut berdasarkan pada potensi desa yang dikembangkan, baik dari alam, adat, teknologi ataupun berbasis pemberdayaan masyarakat. 
Tahun 2018, Pemerintah Kabupaten Sumenep memiliki Program Visit Sumenep 2018 yang bertujuan untuk meningkatan Kesejahteraan Masyarakat Sumenep melalui sektor Pariwisata. Pemkab Sumenep mendukung penuh pembentukan atau pengembangan sektor pariwisata baik yang dikelola oleh BUMDes ataupun dikelola swasta, karena pada intinya sektor pariwisata akan berdampak bagi sektor ekonomi lainnya.

Menurut Suhaimi (2011) dalam Bambang (2016) menjelaskan bahwa potensi desa dibagi menjadi 2 (dua) bagian, yaitu potensi yang bersumber dari Fisik dan potensi yang bersumber dari non fisik desa. Potensi yang berasal dari fisik meliputi potensi dari tanah, air, iklim, lingkungan geografis, binatang ternak, dan sumber daya manusia. Sedangkan potensi non fisik meliputi masyarakat dan interaksinya, organisasi sosial, lembaga pendidikan, masyarakat dan aparatur desa.

Desa Sendir merupakan salah satu desa yang ada di Kabupaten Sumenep tepatnya di Kecamatan Lenteng dengan potensi alamnya adalah bambu. Bambu yang terdapat di Desa Sendir juga dijadikan sebagai mata pencaharian oleh warga dengan cara dijadikan nampan, bakul atau kipas sate yang dijual berkisar Rp. 10.000 hingga Rp. 30.000perbuahnya. Selain itu, bambu merupakan salah satu potensi desa yang dapat dikembangkan menjadi wisata, namun di desa Sendir bambu belum dimanfaatkan sebagai destinasi wisata untuk mendukung program Visit Sumenep 2018 yang sedang digalakkan oleh Pemkab Sumenep. Sementara beberapa desa di Indonesia memanfaatkan bambu sebagai wisata kerajinan dan kesenian.

Menurut Medlik:1980 dalam Harani dkk (2017), terdapat 4 (empat) aspek yang perlu diperhatikan untuk mengenali potensi wisata disuatu daerah yaitu, Attraction (daya tarik), daya tarik menurut Undang-Undang RI No. 10 tahun 2009 Tentang kepariwisataan bahwasanya daya tarik ialah segala sesuatu yang memiliki keunikan, kemudahan, dan nilai yang berupa keanekaragaman kekayaan alam, budaya, dan hasil buatan manusia yang menjadi sasaran atau kunjungan wisatawan. Kedua yaitu Accesability (aksesabilitas), yang diartikan sebagai sistem jaringan transportasi untuk mencapai tujuan kawasan wisata yang dituju. Akses menuju objek wisata tersebut biasanya didukung oleh sarana dan prasarana yang nyaman dan lengkap sesuai kebutuhan wisatawan. Ketiga Amenities (fasilitas), Fasilitas yang harus tersedia ditempat wisata yaitu fasilitas yang berkaitan dengan kebutuhan wisatawan seperti toilet umum, tempat 
ibadah, penjual makanan dan oleh-oleh khas daerah tersebut, tempat duduk yang nyaman, spot foto yang menarik, tempat yang bersih, tempat parkir yang aman dan lain sebagainya. Keempat, Ancillary (kelembagaan), pariwisata berada dibawah naungan dinas pariwisata kabupaten atau daerah. Namun, tiap desa memiliki paguyuban pariwisata yang bernama Kelompok Sadar Wisata (Pokdarwis) untuk memantau, mengembangkan dan melindungi kawasan wisata.

Permasalahan dalam penelitian ini yaitu banyaknya daerah yang menjadikan bambu sebagai objek wisata, namun bagaimana jika potensi bambu yang ada di desa Sendir Kecamatan Lenteng Kabupaten Sumenep dimanfaatkan sebagai destinasi wisata? Dengan tujuan khusus yaitu untuk menjadikan potensi bambu sebagai objek pariwisata dalam rangka mendukung program pemerintah yang akan menjadikan Sumenep sebagai kota pariwisata.

\section{METODE}

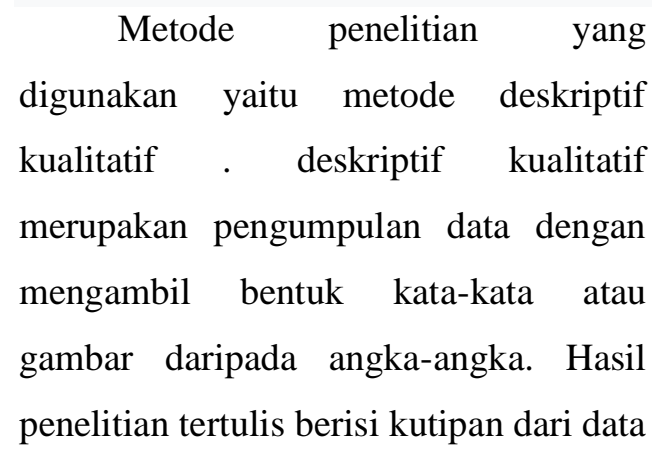

untuk mengilustrasikan dan meyediakan bukti. (Emzir : 2016) Jenis penelitian deskriptif kualitatif yang digunakan pada penelitian ini dimaksudkanuntukmemperolehinformasi mengenai potensi bambu yang dapat dijadikan objek wisata di desa Sendir Kecamatan Lenteng Kabupaten Sumenep.

Metode pengumpulan data merupakan aspek yang memiliki peranan penting dalam memperoleh data penelitian. Dalam metode pengumpulan data yang digunakan dalam penelitian ini ada dua yaitu:

1. Wawancara yang dilakukan terhadap beberapa informan diantaranya:

a) Kepala Desa Sendir dan aparaturnya yang bertujuan untuk mengetahui keseluruhan informasi mengenai bambu dan kegunaannya yang ada di desa Sendir .

b) Masyarakat terkait yang menggunakan bambu sebagai mata pencaharian atau tidak.

c) Pemerintah Kabupaten Sumenep yaitu Kepala DISBUDPARPORA, Kepala Dinas Pemerintahan Desa Kabupaten Sumenep, dan Camat Lenteng Kabupaten Sumenep.

d) Pemandu Wisata Kabupaten Sumenep 
2. Obesrvasi dalam penelitian ini dilakukan secara langsung, artinya peneliti akan melaksanakan tinjauan langsung kepada objek yang dituju, dalam hal ini peneliti akan berkunjung ke Desa Sendir Kecamatan Lenteng Kabupaten Sumenep.

Teknik Analisis Data yang dilakukan oleh penulis ada 3 tahapan yaitu:

1. Reduksi Data

Reduksi data merupakan langkah untuk memilih, memusatkan, memperhatikan, menyederhanakan, mengabstraksikan dan mentransformasi data yang ada pada hasil wawancara maupun observasi.

Adapun data yang akan direduksi dalam penellitian ini berkaitan dengan:

a. Seberapa besar Potensi Bambu untuk dijadikan objek wisata.

b. Seberapa Besar Manfaat Wisata bambu untuk meningkatkan perekenomian masyarakat desa Sendir kec. Lenteng Kab. Sumenep.

c. Ketertarikan Pemerintah dalam mengembangkan potensi wisata bambu di desa Sendir kec. Lenteng Kab. Sumenep.

Data yang sudah diperoleh selanjutnya di reduksi sebagai bahan untuk menyajikan data dalam pembahasan.
2. Penyajian Data

Proses kedua setelah reduksi data adalah penyajian data. Data yang disajikan dalam penelitian ini yaitu menjelaskan hasil dari penelitian yang peneliti lakukan dengan cara mengumpulkan data melaui observasi dan wawancara. Dalam penyajian data penulis dapat mengetahui bagaimana potensi bambu yang akan dijadikan sebagai objek wisata, baik wisata kerajinan bambu ataupun wisata alam dan kegiatan-kegitan seperti festival desa.

3. Menarik kesimpulan.

Proses analisis data selanjutnya yaitu penarian kesimpulan. Penarikan kesimpulan dalam penelitian kualitatif dapat menjawab rumusan masalah yang dirumuskan sejak awal dan dijelaskan dalam pembahasan untuk selanjutnya disimpulkan dalam bab kesimpulan atau konklusi yang berupa data ada atau tidaknya potensi bambu yang terdapat di Desa Sendir Lenteng untuk dijadikan tempat wisata berdasarkan indikator potensi, baik potensi fisik maupun potensi non fisik desa.

\section{HASIL PENELITIAN}

\section{Potensi Desa}

Menurut Suhaimi (2011) dalam Bambang (2016) menjelaskan bahwa potensi desa dibagi menjadi 2 (dua) bagian, yaitu potensi Fisik dan potensi 
non fisik. Potensi fisik meliputi potensi tanah, air, iklim, lingkungan geografis, binatang ternak, dan Sumber Daya Manusia. Sedangkan potensi non fisik meliputi masyarakat dan interaksinya, organisasi sosial, lembaga pendidikan, masyarakat dan aparatur desa.

Potensi fisik di Desa Sendir Kecamatan Lenteng Kabupaten Sumenep dapat ditunjukkan yaitu:

1. Ladang dan persawahan. Ladang dan persawahan masih tergolong produktif, yaitu menghasilkan 3 (tiga) kali panen dalam setahun diataranya padi pada musim hujan, tembakau atau semangka pada musim kemarau. Sedangkan jeda diantara musim kemarau dan penghujan atau antara musim penghujan dan kemarau dapat ditanami jagung ataupun kacangkacangan seperti kedelai dan kacang hijau.

2. Ternak. Mayoritas pencaharian masyarakat Desa Sendir Kecamatan Lenteng Kabupaten Sumenep memiliki mata pencaharian bertani dan beternak. Adapun hewan ternak yang umumnya dijadikan hewan ternak yaitu sapi dan kambing, serta hampir setiap orang memelihara ayam sebagai penghasilan tambahan atau sekedar dikonsumsi sendiri.
3. Pohon Bambu. Desa Sendir Kecamatan Lenteng Kabupaten Sumenep memiliki luas wilayah 439,61 Ha dengan perkiraan $40 \%$ diantara lahan tersebut merupakan kebun bambu. Pohon bambu dimanfaatkan oleh sebagian masyarakat Desa Sendir sebagai penambah penghasilan selain bertani, yaitu dengan dibuat nampan bambu. Pembuatan nampan bambu tersebut memang sudah menjadi kegiatan turun temurun didesa tersebut. Seperti yang diungkapkan oleh Hairul sebagai anggota pemuda sendir (Perdasi):

"bambu dimanfaatkan masyarakat untuk dijadikan penghasilan tambahan, yaitu dijadikan kerajinan dandang bambu atau anyaman bambu, tapi saat ini sudah hampir punah bak, karena anak mudanya tidak menekuni pekerjaan itu lagi"

4. Sungai Kembar. Desa Sendir merupakan desa yang secara geografis berbatasan dengan Desa Batuan dan Desa Torbang disebelah utara, disebelah selatan Desa Sendir berbatasan dengan Desa Muangan, sebelah barat Desa Sendir berbatasan dengan Desa Meddelan, dan sebelah timur Desa Sendir berbatasan dengan Desa Nambakor dan Desa Patean. Desa Sendir juga merupakan muara akhir untuk 
aliran sungai sehingga terdapat sungai disebelah timur desa yang posisinya sejajar atau biasa disebut dengan nama sungai kembar. Sungai Kembar ini banyak dijadikan sebagai tempat aktivitas warga seperti mandi dan mencuci pada saat musim kemarau alasannya karena desa kekeringan air, ataupun sebagai tempat menangkap ikan pada saat musim hujan.

5. Makam Raja. Di Desa Sendir terdapat makam keramat yang bernama "Astah Agung Rahwan". Makam tersebut banyak dikunjungi oleh masyarakat diluar Desa Sendir, Agung Rahwan merupakan salah satu ulma besar Sumenep pada abad ke 15. Agung Rahwan merupakan keturunan dari sunan kudus. (Babad Soengennep : 1914)

\section{Potensi Wisata Desa Sendir}

Menurut medlik:1980 dalam harani dkk (2017), terdapat 4 (empat) aspek yang perlu diperhatikan untuk mengenali potensi wisata disuatu daerah yaitu:

1. Attraction (daya tarik), daya tarik menurut Undang-Undang Republik Indonesia No. 10 tahun 2009 Tentang kepariwisataan bahwasanya daya tarik merupakan satu hal yang memiliki keunikan, kemudahan, dan nilai yang berupa keanekaragaman kekayaan alam, budaya, dan hasil buatan manusia yang menjadi sasaran atau kunjungan wisatawan. Di Indonesia terdapat beberapa daerah atau desa yang sukses mengembangkan pariwisata bambu, seperti: Hutan Bambu Surabaya, Hutan Bambu Lumajang, Boekit Tinggi Daramista, Wisata Taman Gazebo Bambu Surabaya, Hutan Bambu Tabanan Bali, Istana Bambu Karang Kenik Situbondo, HutanWisata Bambu Bulaksalak Klaten Jawa Tengah, Wana Wisata Negeri Bambu Pasuruan, dan Dusun Bambu Kabupaten Bandung. Atas dasar suksesnya wisata bambu di beberapa daerah tersebut, dimungkinkan dapat diterapkan di Desa Sendir. Daya tarik bambu yang ada di Desa Sendir dapat dipetakan dari beberapa hal, diantaranya :

a. Pohon bambu sebagai wisata pemandangan.

Berdasarkan destinasi wisata bambu yang ungkapkan diatas, maka dapat dijadikan sebagai bahan rujukan bagi Desa Sendir untuk mengembangkan potensi bambu sebagai objek Wisata 
b. Area pohon bambu sebagai pasar desa.

Salah satu kekayaan desa yang dapat menghasilkan Pendapatan Asli Desa (PADes) adalah Pasar Desa. Berdasarkan observasi yang dilakukan di Desa Sendir, terdapat sebagian warganya yang bekerja sebagai penjaja makanan, adapula yang menjajakan syurn beserta kebutuhan pokok rumah tangga lainnya. Potensi untuk menjadikan bambu sebagai pusat kegiatan masyarakat dalam bertransaksi sehari-hari menjadi sangat menguntungkan desa.

c. Pohon bambu dan aneka produk bambu.

Di Desa Sendir Kecamatan Lenteng Kabupaten Sumenep, bambu dijadikan sebagai mata pencaharian tambahan yaitu nampan bambu yag dijual oleh pengrajin kepada pengepul. Dengan membuat diversifikasi produk bambu menjadi kerajinan lain seperti souvenir dan hiasan lainnya yang dapat menambah daya tarik wisatawan.
2. Accesabilty (akesabilitas).

Aksesabilitas dapat diartikan sebagai sistem jaringan transportasi untuk mencapai tujuan kawasan wisata yang dituju. Akses menuju objek wisata tersebut biasanya didukung oleh sarana dan prasarana yang nyaman dan lengkap sesuai kebutuhan wisatawan, seperti : jalan yang bagus, MCK umum yang tersedia diberbagai tempat, tempat ibadah, SPBU, penginapan, tempat makan, dan toko souvenir khas daerah. Desa Sendir letaknya mudah diakses, tidak jauh dari Kota Sumenep. Adapun sarana dan prasarana seperti yang telah disebutkan diatas memang cukup tersedia di akses jalan menuju Desa Sendir.

3. Amenities (fasilitas)

Fasilitas yang harus tersedia ditempat wisata yaitu fasilitas yang berkaitan dengan kebutuhan wisatawan seperti toilet umum, tempat ibadah, penjual makanan dan oleh-oleh khas daerah tersebut, tempat duduk yang nyaman, spot foto yang menarik, tempat yang bersih, tempat parkir yang aman dan lain sebagainya. Apabila Desa Sendir ingin menjadikan bambu sebagai objek wisata, maka harus menyediakan fasilitas yang 
dibutuhkan oleh wisatawan tersebut.

4. Ancillary (kelembagaan)

Kelembagaan pariwisata berada dibawah naungan dinas pariwisata kabupaten atau daerah. Namun, tiap desa memiliki paguyuban pariwisata yang bernama Kelompok Sadar Wisata (Pokdarwis) untuk memantau, mengembangkan dan melindungi kawasan wisata. Di Desa Sendir telah memiliki kelompok anak muda yang bernama PERDASI.

\section{Potensi SDM Masyarakat Desa}

- Pola Pikir

Pola pikir merupakan kepercayaan atau keyakinan cara berpikir individu yang mempengaruhi perilaku dan sikap seseorang yang akhirnya akan menentukan level keberhasilan hidupnya.

Berdasarkan hasil wawancara dengan masyarakat dan tokoh masyarakat Desa Sendir mengenai bambu yang akan dijadikan objek wisata.

"waktu itu pernah akan digagas oleh PERDASI, namun ada masyarakat dan tokoh masyarakat yang tidak menyetujui, takut dijadikan tempat pacaran oleh pengunjung wisata" (pernyataan Kepala Desa Sendir)
Berbeda halnya dengan yang disampaikan oleh salah satu anggota PERDASI, bahwasanya:

“ kami tidak mendapatkan dukungan dari beberapa pihak, sebenarnya sudah ada inisiasi untuk mengembangkan bambu, baik sebagai objek wisata maupun sebagai kerajinan tangan untuk menambah nilai ekonomi dari bambu itu sendiri."

- Keinginan megembangkan diri Menurut Marmawi, pengembangan diri merupakan suatu proses meningkatkan kemampuan atau potensi, dan kepribadian serta sosial emosional seseorang agar terus tumbuh dan berkembang.

Keinginan mengembangkan diri pada masyarakat Sendir tercermin dalam sikap dan pola pikir, hal ini ditunjukkan dari hasil wawancara dengan tokoh masyarakat dan beberapa perwakilan masyarakat Desa Sendir Kecamatan Lenteng Kabupaten Sumenep.

Menurut Bapak Saleh (Tokoh Masyarakat) menyampaikan pendapatnya terkait pariwisata dan bambu di desa tersebut.

" kami tidak masalah dengan pariwisata, namun yang tidak membawa mudharat kepada kehidupan warga Sendir. Sedangkan bambu, bambu disini 
dijadikan sebagai penopang perekonomian warga, membantu warga dengan cara dibuat geddheng"

\section{Potensi BUMDES}

Menurut Sutro, dkk (2014) terdapat 6 (enam) klasifikasi usaha yang dapat diterapkan pada BUMDes, yaitu:

1. Serving (bisnis sosial) : usaha air minum desa, suling air, listrik desa, lumbung pangan.

Desa Sendir hanya memiliki usaha air minum desa yang telah berjalan kurang lebih 2 (dua) tahun, namun usaha air minum desa tersebut milik perorangan (bukan milik desa)

2. Banking : banking atau yang dikenal dengan usaha simpan pinjam belum nampak ditemukan di desa Sendir, hanya terdapat acara perkumpulan sosial kemasyarakatan masyarakat Desa Sendir yang diadakan setiap minggu atau setiap bulan yang dikemas dengan sistem arisan. Dan untuk simpan pinjam permodalan dan sejenisnya, di desa tersebut hanya terdapat BTPN syariah yang masuk ke desa tersebut.

3. Renting : persewaan yang dikelola oleh BUMDes biasanya desa memiliki persewaan terop dan segala hal yang berkaitan dengan perlengkapan pernikahan. Di Desa Sendir belum nampak hal seperti itu, hanya ada 2 (dua) buah tenda milik kepala desa pribadi

4. Broker : usaha broker juga merupakan usaha paling mudah dilakukan oleh desa seperti pembayaran listrik, PDAM, Telp, perpanjangan pajak motor, pemasaran hasil pertanian, pupuk, dll. Mengingat lokasi desa Sendir secara geografis jauh dari Kota. Di Desa tersebut hanya ada satu toko klontong dan sekaligusmenjadi agen pembayaran salah satu perbankan.

5. Trading : trading atau perdagangan merupakan usaha yang lumrah dilaksanakan oleh beberapa Desa yang memiliki BUMDes, biasanya berbentuk swalayan atau toko retail dan grosir. Di Desa Sendir belum terdapat toko atau swalayan yang melayani pembelian eceran dan partai yang dikelola oleh desa. Namun jika dikembangkan di Desa tersebut kemungkinan akan diterima baik oleh masyarakat mengingat lokasi desa yang jauh dari pusat perbelanjaan.

6. Holding : menurut Yunus dan Harnanto (2009) merupakan suatu perusahaan yang dibentuk dengan tujuan khusus, yaitu untuk mendapatkan saham-saham dan mengendalikan operasional perusahaan lain. Holding ini 
diminati oleh beberapa BUMDes karena salah satu kelebihannya yaitu bisa berbagi dan memberikan bantuan serta dukungan teknis kepada BUMDes lainnya sesuai jenis usaha masing-masing. Di Desa Sendir atau Kabupaten Sumenep belum terdapat holding BUMDes.

\section{KESIMPULAN DAN SARAN}

Desa Sendir memiliki potensi untuk dijadikan tempat pariwisata dengan bambu sebagai objek wisatanya. Hal ini ditinjau dari aspek potensi wisata yang perlu diperhatikan untuk mengenali potensi wisata disuatu daerah yaitu: Attraction (daya tarik), Accesabilty (akesabilitas), Amenities (fasilitas), dan Ancillary (kelembagaan). Namun Desa Sendir harus memperhatikan beberapa faktor penghambat untuk dicarikan solusi agar terbentuknya desa wisata bambu di Desa Sendir didukung oleh semua pihak yaitu masyarakat dan pemerintah, hal ini sesuai dengan undang - undang No. 06 Tahun 2014 tentang Desa bahwasanya pengembangan potensi desa bertujuan untuk mendorong terwujudnya kemandirian masyarakat melalui pengembangan potensi unggulan dan penguatan kelembagaan serta pemberdayaan masyarakat. Serta Potensi Wisata Bambu tersebut dapat pula dikembangkan sebagai Badan Usaha
Milik Desa di Desa Sendir, mengingat di desa tersebut, BUMDes yang terbentuk belum berjalan optimal.

Terdapat beberapa saran dalam penelitian ini yaitu:

Bagi Desa hendaknya kenali potensi desa dengan baik untuk memudahkan mengembangkan desa dan mensejahterakan masyarakat.

Bagi pemerintah hendakya memperhatikan beberapa desa yang memiliki potensi desa yang baik, sebab masyarakat akan ikut serta berpartisipasi apabila pemerintah proaktif mengembangkan pariwisata.

Bagi peneliti selanjutnya, disarankan melakukan indepth interview mengenai perilaku masyarakat dalam keikutsertaannya mengembangkan desa, ditinjaudari segi kebutuhan ekonomi maupun sosio politik.

\section{DAFTAR PUSTAKA}

Anonim. 2012.Analisis potensi dan pengembangan wisata kota tumohon. Universitas kristen Satya Wacana.

Bambang. 2016. Pemetaan Potensi Desa di Kabupaten Banyumas. Economic, Social, and Development Studies. Jurusan Ilmu Ekonom FEBI Universitas Alaudin. Makasar

Cahyono, Arie Eko dan Yudha Bagus Tunggala. 2017. Analisis Potensi Ekonomi pengembangan Agrowisata Berbasis kearifan Lokal di Desa Wisata Sumbermuju Kabupaten Lumajang. Eco Sosio : jurnal Ilmu dan Pendidikan Ekonomi Sosial 
Vol.1 No.1 November 2017. IKIP PGRI JEMBER

Emzir. 2016. Metodologi Penelitian Kualitatif. Rajawali pers. Jakarta

Hadi, Mohammad. 1996. Babat Sumenep. Balai Pustaka

Marjoko. 2010. Analisis Potensi dan Pengembangan Objek Wisata Air Umbul Ingas di Kecamatan Tulung Kabupaten Sleman tahun 2008. FKIP. Unversitas sebelas Maret. Surakarta

Narsi, Wiwi dkk. Resort di Tumohon. Uniersitas Sam Ratulangi.

Profi Desa Sendir Kecamatan Lenteng Kabupaten Sumenep

Putri, Kiki Amalia dkk. 2017. Penentuan potensi wisata Prioritas melalui Pendekatan Community-Based Tourism di Desa Wisata Teritip Kota Balikpapan. Journal of Regional and Rural Development Planning Oktober 2017, 1 (3): 298-306 DOI: http://dx.doi.org/10.29244/jp2wd. 2017.1.3.298-306
Soleh, Ahmad. 2017. Strategi Pengembangan Potensi Desa. Jurnal Sungkai Edisi Februari Hal 32 - 52. Universitas Padjajaran. Bandung

Sugiyono. 2013. Metodelogi Penelitian Kuantitatif, Kualitatif dan R\&D. Bandung. Alfabeta

Undang-undang Nomor 6 tahun 2014 tentang Desa

Undang-undang No. 16 Tahun 2009 tentang kepariwisataan

Wardani, Aristya Wiracitra A. dan Prihatmaji, Yulianto P. 2014. pemanfaatan bambu sebagai solusi permasalahan karst dan pemberdayaan masyarakat di kawasan wediombo geopark. Jurusan Arsitektur Fakultas Teknik Sipil dan Perencanaan UII, Yogyakarta

Yabbar, Rahmah dan Ardi Hamzah. 2016. Tata Kelola Pemerintahan Desa. Penerbit Pustaka. Surabaya. 